\title{
FISH DISEASES AND STRATEGIES TAKEN BY THE FARMERS IN FRESHWATER AQUACULTURE AT SOUTHWESTERN BANGLADESH
}

\author{
Sheikh Aftabuddin, M. Nurul Islam¹, Mohammad Abdul Baten Bhuyain ${ }^{1}$, \\ M. Abdul Mannan ${ }^{1}$ and M. Mahbub Alam²* \\ Institute of Marine Sciences and Fisheries, University of Chittagong, \\ Chittagong 4331, Bangladesh
}

\begin{abstract}
To understand the present status of fish diseases and their remedial measures taken by the fish farmers, a questionnaire survey and Participatory Rural Appraisal (PRA) tools including Focus Group Discussion (FGD) were conducted in seven districts of Bangladesh. In total 196 farmers were interviewed and nine FGD sessions were conducted. Disease occurs immediately after stocking $(24 \%)$ and during the rainy season $(21 \%)$ followed by cold season $(19 \%)$. Mortality, abnormal swimming and feeding behavior, unusual appearance, some localized lesions and reduced growth are the main clue to recognize the fish disease. The most frequently observed diseases were epizootic ulcerative syndromes $(18.72 \%)$ followed by tail and fin rot (13.19\%), red spot (11.49\%), gill rot $(9.36 \%)$, parasitic disease $(8.93 \%)$, broken prawn antennae $(7.23 \%)$, and other environmental and nutritional diseases. To cure these diseases, farmers applied the following treatments: lime and potash, liming, lime and salt, lime alone, salt and potash, antibiotics, various chemicals, high doses of vitamin C, complete water exchange, and transport to another pond. This study showed that diseases can play important roles in freshwater aquaculture, but this role is often not recognized due to a lack of knowledge and veterinary backstopping services.
\end{abstract}

Key words: Fish disease, antibiotics, chemicals, remedial measures

\section{INTRODUCTION}

Fisheries sector plays an important role in the national economy of Bangladesh, and also in rural employment generation and poverty alleviation. This sector contributed $3.69 \%$ to national GDP and $22.60 \%$ of the agricultural GDP in 2013 - 2014 (BER 2015). Fish provide 60\% of the national animal protein necessity. In 2013-2014 fiscal year, the estimated total fish production was 3.548 million metric tons, of which 0.996 million metric tons $(28.073 \%)$ were obtained from inland capture fisheries, 1.957 million metric tons (55.15\%) from inland culture fisheries and 0.595 million metric tons (16.78\%) from marine fisheries (DoF 2015). The average annual growth rate of fish production in the last 3 years was $6.11 \%$. The production of inland aquaculture sector is increasing day by day due to dissemination of adaptive and new technologies and need-based extension services rendered by the Government of Bangladesh, various donor agencies and NGOs.

*Corresponding author: aftabims@cu.ac.bd, ${ }^{1}$ Department of Fisheries, University of Rajshahi, Rajshahi-6205, Bangladesh. ${ }^{2}$ Marine Fisheries Discipline, Marine Fisheries Academy, Fish Harbor, Chittagong-4000, Bangladesh.

(C) 2016 Zoological Society of Bangladesh DOI: 10.3329/bjz.v44i1.30181 
Aquaculture is the fastest growing industry around the world and Bangladesh is no exception. Aquaculture production, especially pond aquaculture, is depends upon sources of obtaining increased fish production in order to supply and feed the ever-increasing population of the world (FAO 2010). The main culture system for freshwater aquaculture in Bangladesh is extensive and semi-intensive polyculture of Indian and Chinese major carps, which represent near about $70 \%$ of the total freshwater production and this production are mostly exploited for local consumption. The rest $30 \%$ are generally from tilapia, catfish, prawn and small indigenous species of fish and rice fish farming (DoF 2010). Recently, farmers of Bangladesh are becoming more attention in the homestead pond as an important, valuable cheap protein and vitamin suppliers (Ahmed et al. 2007). The total area brought under inland culture is 800,705 hectares in 2014 (DoF 2015).

There is no doubt that the fish culture has developed into a major industry in Bangladesh. The majority of fish production of Bangladesh comes from rural freshwater aquaculture (Islam, 2001). Rural aquaculture is the most extensive or improve extensive systems, low-cost farming of aquatic organisms by farming households or communities, using technology appropriate to their resource base (Edwards and Demaine 1997). The success of fish culture depends on its proper management, which is connected with understanding the life cycle of fish and the culture environment in which they live. However, failures in fish production occurred due to indiscriminate and unplanned use of feed and fertilizer, overstocking that increase stress on fish and enhance their susceptibility to various pathogens led to diseases. The effects of diseases on traditional and semi-intensive culture system are significant. The noticeable effect of the diseases is mortalities in the fish population, followed by economic losses. Faruk et al. (2004) reported the average economic loss of BDT 20,615/ha/year (equal to US\$ 344) to rural freshwater fish farmers due to fish disease in Bangladesh. This value was equivalent to approximately $15 \%$ of the total production. Such loss affects the livelihood of poor people involved in the aquaculture sector. Disease is considered one of the important factors to decrease in fish production, both in farming system and in wild condition. Large-scale mortality of fish often occurs in ponds due to environmental stress followed by parasitic invasion and bacterial, fungal, protozoan and monogenean infections (Hossain et al. 2011).

There are a few diagnostic laboratories or support services in Bangladesh and all of these laboratories are placed in universities or governmental Research Centers which are far away from rural fish farms. In view of the fact farmers do not understand the signs of diseases, they do not report the occurrence of diseases. The majorities of disease symptoms and effects in coastal and rural 
aquaculture sector became unobserved. Laboratory analysis is preferred for the detection of disease and their causing pathogens. The government fisheries officers diagnosed a limited number of samples, which is insufficient for the country. Field survey is the most practical method in collecting such information directly from a vast area and a large number of farmers.

A few data are available on the status and consequences of fish disease in fresh water aquaculture of the southwestern part of Bangladesh. The main objectives of this study was to know the present status of freshwater aquaculture fish diseases in the southwestern part of Bangladesh and to evaluate the existing knowledge and measures taken by the fish farmers on disease management.

\section{MATERIAL AND METHODS}

Study area and period: The survey was carried out over a period of two weeks (May 27 - June 11, 2013) in seven districts of southwestern part of Bangladesh namely Jessore, Narail, Khulna, Satkhira. Bagerhat, Barisal and Patuakhali (Fig. 1). These districts are potential for freshwater aquaculture production of the country.

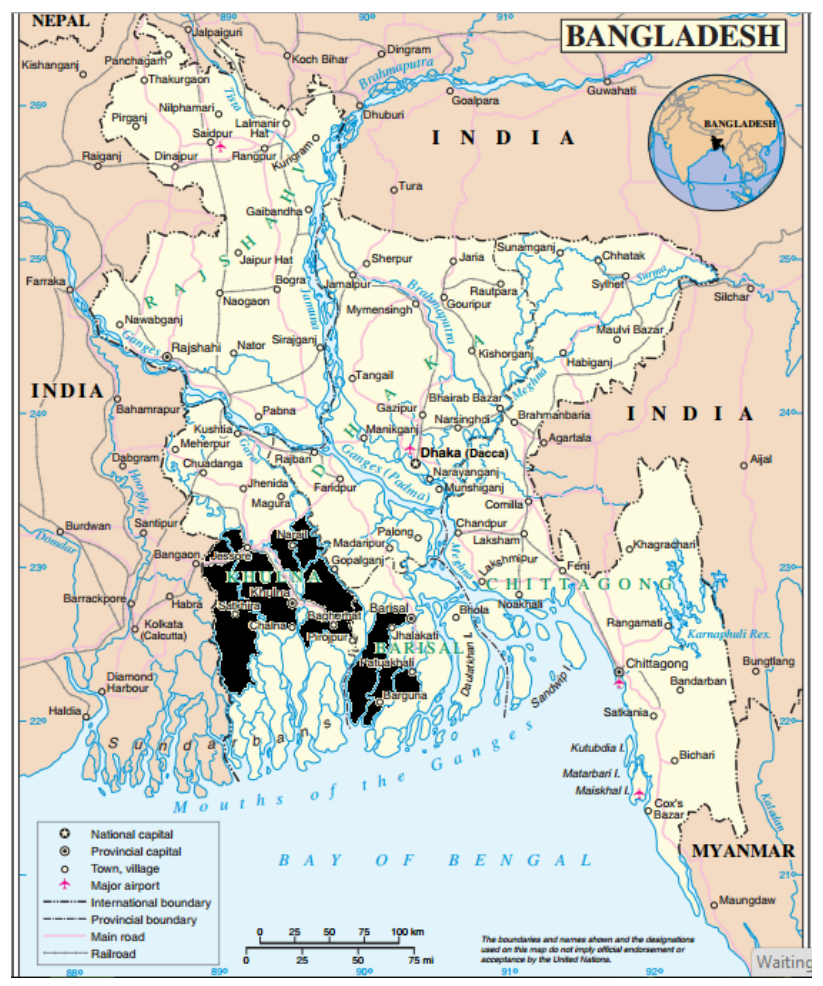

Fig. 1. Investigated area (black) i.e. farmers interviews and focus groups discussion. 
Data collection: Data were collected through the questionnaire interview and Participatory Rural Appraisal (PRA) with fish farmers. For questionnaire interview, 40 preliminary questions were prepared relating to fish health issues, management, prevalence of disease, frequency, farmers' perceptions, knowledge of disease, treatment applied and contact with extension services and other forms of assistance.

PRA tools, including Focus Group Discussion (FGD), were conducted with rural fish farmers to get a general idea of particular issues of fish health and disease. A total of 9 FGD sessions in 7 different districts were conducted and at least 15 farmers were present in each group. Cross check, interviews were conducted with key informants such as officers from the Department of Fisheries (DoF), Upazila fisheries officer, researchers of BFRI, seed traders, feed and medicine suppliers those working with aquaculture.

\section{RESULTS AND DISCUSSION}

The study divides the farmers into three categories depending on their pond size. The first category those who have less than 0.2 ha pond area represented about $40 \%$ of the total farmers interviewed. The second category was medium farmers who had $0.2-0.4$ ha of the pond area and the third category farmers who have over 0.4 ha pond area (Table 1). The average age of the farms was 3.5 years, the oldest being 8 years and the youngest being 1.2 years. The majority of pond owners grow fish for their income $(47 \%)$ the second scored reasons were food fish $(30 \%)$, the third reasons were hobby $(20 \%)$ in which food fish are a production bonus (45\%) for that little capital inputs are necessary and the fourth reason was a status $(3 \%)$.

Table 1. Farmers pond size and reasons for aquaculture

\begin{tabular}{lccc}
\hline $\begin{array}{l}\text { Farm size } \\
\text { (ha) }\end{array}$ & $\begin{array}{c}\text { Percentage of } \\
\text { respondents }\end{array}$ & $\begin{array}{c}\text { Reasons for fish } \\
\text { farming }\end{array}$ & $\begin{array}{c}\text { Percentage of } \\
\text { respondents }\end{array}$ \\
\hline$<0.2$ & 41 & Income & 47 \\
$0.2-0.4$ & 29 & Food & 30 \\
$>0.4$ & 30 & Hobby & 20 \\
& & Status & 3 \\
& & Other & 0 \\
\hline
\end{tabular}

Problems faced by farmers: All farmers were asked to make a score, in order to signify the problems that they were encountered during the fish growing time in the pond (Table 2). The major problem was bad water quality $(27 \%)$, followed by diseases $(25 \%)$, poor quality seeds/fry was ranked in third position and too little water was ranked in fourth. Availability of feed, theft and predation figured in the fifth, sixth and seventh ranking. 
Availability and quality of fry: Half of the farmers said that they were able to choose fry $(49 \%)$, while the other half $(47 \%)$ must take what is available. The same tendency was observed in the question about the physical condition of the fry: $50 \%$ farmers said the fry was healthy, while the remainder $(46 \%)$ did not know.

Table 2. Problems encountered by farmers $(n=196)$

\begin{tabular}{lcccccc}
\hline $\begin{array}{l}\text { Bad water } \\
\text { quality (\%) }\end{array}$ & $\begin{array}{c}\text { Disease } \\
(\%)\end{array}$ & $\begin{array}{c}\text { Low quality } \\
\text { seed/fry } \\
(\%)\end{array}$ & $\begin{array}{c}\text { Too little } \\
\text { water }(\%)\end{array}$ & $\begin{array}{c}\text { Availability of } \\
\text { feed } \\
(\%)\end{array}$ & $\begin{array}{c}\text { Theft } \\
(\%)\end{array}$ & $\begin{array}{c}\text { Predation } \\
(\%)\end{array}$ \\
\hline 27.1 & 25 & 20.8 & 9.37 & 7.3 & 6.25 & 4.17 \\
\hline
\end{tabular}

$\mathrm{n}=$ total number of farmers surveyed.

Farmers' perception of aquaculture: Farmers were asked what they think about the aquaculture business and their responses are presented in Table 3. The majority of farmers (32.37\%) said aquaculture is a profitable business; only a few farmers agreed that aquaculture is a risky business. Diseases were also an important factor, but not in small-scale farms.

Table 3. Farmers' perception of aquaculture $(n=196)$

\begin{tabular}{lc}
\hline & Percentage of positive respondent \\
\hline Aquaculture is a risky venture & 4.31 \\
Aquaculture is a profitable business & 32.37 \\
Aquaculture is only profitable for large scale farmers & 26.98 \\
Disease in aquaculture is an important issue & 20.86 \\
Disease doesn't occur in small-scale farms & 15.47 \\
\hline
\end{tabular}

Disease occurrence: Of the 196 farmers interviewed, $29.16 \%$ reported that they had experienced on disease problems in the last two years, $12.5 \%$ had problems in the last six months and $5.2 \%$ had problems in the last three months. The majority of the farmers said that they had disease problems, but they could not remember when. Most of the farmers said the result of disease problems was that "some" of the fish died. Only three farmers reported that "all" the fish died among them one tilapia farm owners said his farm was completely damaged by disease and two farmers said their farms were partially damaged. The outbreak of the disease reduces the fish consumption rate in few investigated areas. Consequently, the fish trade was also seriously affected. Due to consumer resistance, the traders did not accept such fish for selling. Few farmers said that due to low price in fish market, they cooked the affected fish for their family's nutrition, but the majority of the farmers were buried the disease-affected fish. The impact of the disease to the fish farmers' household is shown in Table 4. 
Farmers were asked, when they observed the disease, in any particular season or completely the growing time. According to the farmers, most of the diseases occurred just immediately after stocking and during the post rainy seasons followed by cold season. Some farmers said before harvesting they have seen some symptoms of disease, few farmers said they saw after flood and draught. Table 5 shows the disease pattern of the present surveyed area.

Table 4. Impact of fish disease problems $(n=196)$

\begin{tabular}{lccc}
\hline Reply & $\begin{array}{c}\text { Positive } \\
(\%)\end{array}$ & $\begin{array}{c}\text { Negative } \\
(\%)\end{array}$ & $\begin{array}{c}\text { No comment } \\
(\%)\end{array}$ \\
\hline Disease affected fish price is low at market & 36.46 & 45.83 & 17.71 \\
Your household income is reduced & 42.71 & 34.38 & 22.91 \\
Your debt is increased & 26.04 & 42.71 & 31.25 \\
Eat the affected fish & 5.21 & 69.79 & 25 \\
\hline
\end{tabular}

Table 5. Season associated with the diseases $(n=196)$

\begin{tabular}{lc}
\hline Season/pattern & \% of respondent \\
\hline During dry season & 8.33 \\
During hot season & 9.37 \\
During cold season & 18.75 \\
During rainy season & 20.83 \\
Just before harvesting & 8.33 \\
Just after stocking & 23.96 \\
Just after flood & 6.25 \\
Just after drought & 4.17 \\
Other & 0 \\
\hline
\end{tabular}

Farmers were asked about their ability to identify disease. Twenty-three percent farmers said that they could identify some diseases, while $15.62 \%$ said that they could not recognize any disease. No one said that he/she could recognize all or most diseases. The ability to recognize disease was based on a number of factors; the most frequently cited were mortality, abnormal swimming and feeding behavior, abnormal appearance, some localized lesions and reduced growth. The most common problems reported are listed in Table 6 . The disease did not seem to cause huge losses; majority of the farmers $(60.4 \%)$ reported that only a few fish died, however, $12.5 \%$ reported where most of the fish died. As the losses were measured by mortalities, it is not possible to estimate the loss of production due to reduced growth. Figs 1-4 show the disease affected fishes and prawn during the present investigation.

According to the farmers report, the most common response to disease was to use of chemicals $(46.16 \%)$ or lime $(19.23 \%)$; $6.15 \%$ farmers used antibiotics. 
Howover, $14.6 \%$ farmers changed water, $3.85 \%$ added salt, $3.08 \%$ removed the fish, $1.54 \%$ stopped feeding, and $3.08 \%$ stopped the fertilizing. Treatments taken by the farmers were presented in Table 7 . The majority of the farmers applied cocktail formula, i.e. lime and potassium permanganate together, lime and salt, lime salt and potash together. Application of liming was the second most common treatment.

Table 6. Problems reported by the farmers and the age of fish affected

\begin{tabular}{lccc}
\hline $\begin{array}{l}\text { Disease } \\
\text { signs }\end{array}$ & $\begin{array}{c}\text { Frequency observed } \\
\text { by farmers }\end{array}$ & $\begin{array}{c}\text { \% of farmers } \\
\text { responded }\end{array}$ & $\begin{array}{c}\text { Age of fish } \\
\text { (days) }\end{array}$ \\
\hline Fish gasp & 3 & 4.26 & $110-120$ \\
Swollen belly & 2 & 5.11 & $50-250$ \\
White discoloration & 2 & 3.40 & $110-120$ \\
Red spot & 2 & 11.49 & $80-90$ \\
Deformed head (cat fish) & 2 & 4.26 & 80 \\
Tail and fin rot & 4 & 13.19 & $80-90$ \\
Gill rot & 3 & 9.36 & $90-150$ \\
Broken antennae (Prawn) & 4 & 7.23 & $110-130$ \\
Whirling disease (Tilapia) & 3 & 4.26 & $90-95$ \\
Soft muscle (Prawn) & 2 & 6.38 & $90-120$ \\
Loss of mucus & 2 & 3.40 & 150 \\
Epizootic Ulcerative & 5 & 18.72 & $90-95$ \\
Syndrome (EUS) & & & \\
Parasite infection (Agrulosis) & 3 & 8.94 & 90 \\
\hline
\end{tabular}

Table 7. Antibiotics/chemicals added by number of farmers

\begin{tabular}{lc}
\hline Strategies & \% of farmers adopted \\
\hline Change the water & 14.6 \\
Add lime into the pond & 19.23 \\
Add antibiotic into the pond & 6.15 \\
Add salt into the pond & 3.85 \\
\hline Add chemical into the pond & $146.16 \%)$ \\
a. Potassium Permanganate $\left(\mathrm{KMnO}_{4}\right)$ & 12.31 \\
b. Zeolite & 9.23 \\
c. Virex*(Potassium Peroxymono sulphate $50 \%)$ & 6.92 \\
d. Timsen* (n-Alkyldimethylbenzyl ammonium chloride & 11.54 \\
e. $\quad$ Copper sulphate & 3.85 \\
f. Potash alum & 2.31 \\
\hline Put formalin into the pond & 0 \\
Remove the fish from the pond & 3.08 \\
Stop feeding & 1.54 \\
Stop fertilizing into the pond & 3.08 \\
Other unspecified measures of the pond & 2.31 \\
\hline
\end{tabular}

*Commercial brands. 

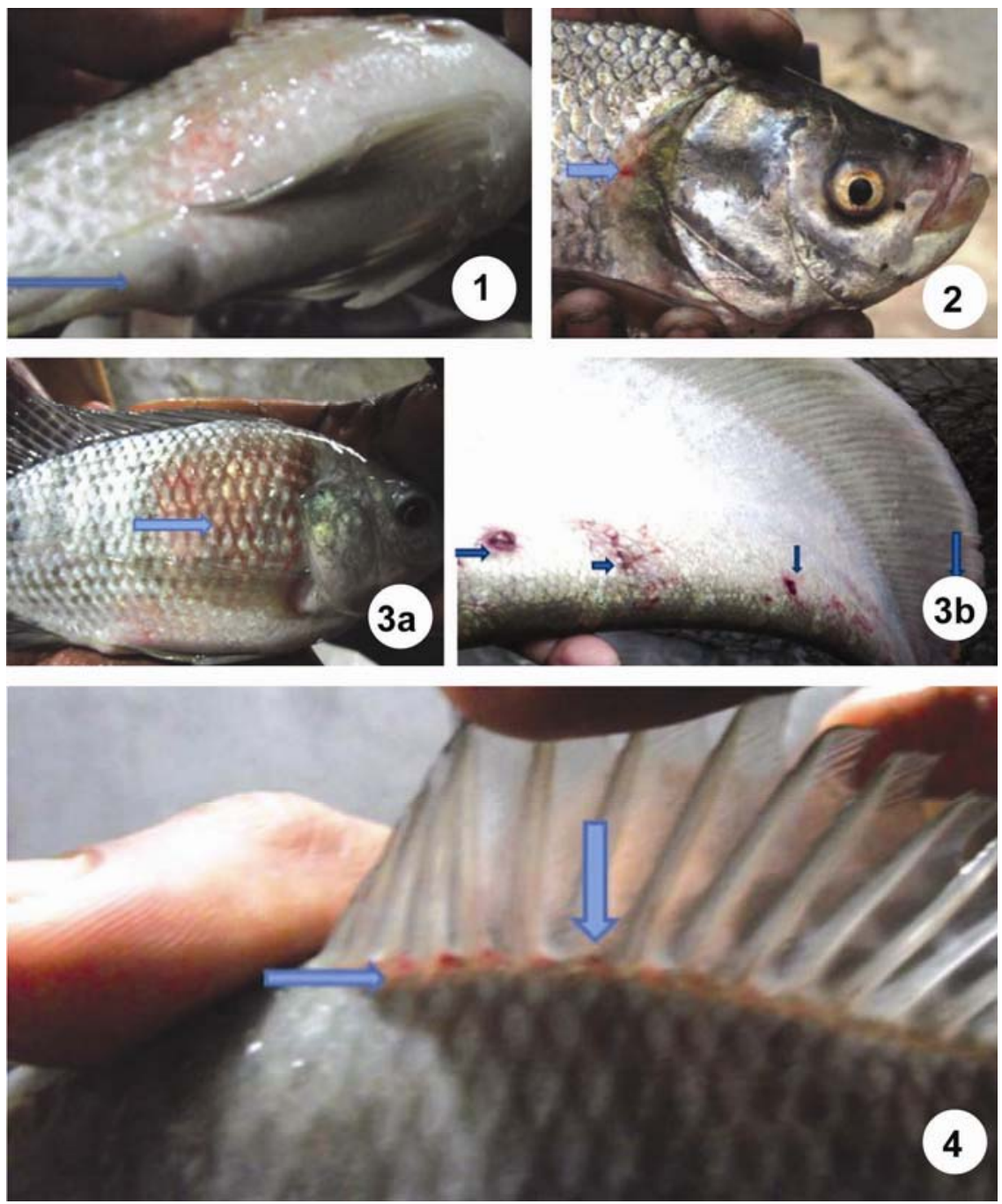

Figs 1-4: 1. Swollen belly disease of tilapia fish at Jessore. 2. Dactylorosis and gyrodactylorosis disease of Carp fish (Catla catla) at Jessore district. 3. Epizootic ulcerative syndrome (EUS) disease of Tilapia fish (a) and Chitol fish (Chitala chitala) (b) at Barisal. 4. Parasitic infection at dorsal site (under dorsal fin).

Problems relating to the quality of water in aquaculture systems are very diverse. A careful balance of nutrients and other factors is essential to maintain the optimum culture conditions required for fish health. These factors include temperature, salinity, $\mathrm{pH}$, hardness and the balance between nitrogen, oxygen and phosphorus amongst many others.

In Bagerhat and Khulna districts, some farmers had stocked Penaeus monodon seeds with carp fish fry (rhui, catla, grass carp etc.) in their culture pond. They claimed that the seed traders did not give them healthy seeds, for 
this reason mortality rate is high and the production rate is very low and they are loosing money every year. During the onside farm investigation, the present study found that the farm water salinity was almost zero which is intolerable salinity for $P$. monodon, besides this, the $\mathrm{pH}$, DO and hardness level were not suitable for fish culture. The farmers never check the water quality parameters and they never justify that their pond is suitable for shrimp culture or fish culture. While the production failed all they blamed that the seed/fry quality was bad but they do not worry their culture pond water quality, which was crucial for aquaculture.

The application of fertilizers is also important in boosting the productivity of a system. The use of aquatic fertilizers and other commercial water treatment products in the surveyed area of Bangladesh has increased dramatically, and is reflected in the range of organic and inorganic products available on the market. Some of them are Dolomite, Zeolite Gold, Polgard+, Oxygold etc. of Fishtech Bd limited.

This study found a variety of diseases occurred in freshwater aquaculture in southwestern part of Bangladesh. The most prevalent disease was EUS, followed by tail and fin rot, gill rot, parasitic (Argulosis), broken antennae (freshwater prawn), black discoloration, red spot and swollen belly. Parallel results were reported by Faruk et al. (2004) who worked at 5 other districts i.e. Mymensingh, Comilla, Jessore, Natore and Dinajpur of Bangladesh. In their study, tail and fin rot was the most prevalent disease followed by EUS, nutritional, red spot and gill rot disease.

The epizootic ulcerative syndrome (EUS) disease is a major problem for freshwater aquaculture in Bangladesh. The causative agent of EUS is Aphanomyces invadans (Lilley et al. 1998), which causes severe liquefactive necrosis of muscle tissue as it invades the body. A variety of parasites has also been reported from diseased fish, but their presence is inconsistent (Lilley et al. 1998). It was first reported in Japan in 1971, followed by Australia in 1972, the USA in 1978, south and south east Asia in 1986, southern Africa in 2007 and Canada in 2010 (DFS, 2015). In Bangladesh, the EUS was first reported in 1998 (Lilley et al. 1998). EUS now affects 25 countries in four continents: Africa, Asia, Oceania and North America. Over 100 freshwater fish species and a number of brackish water fish are susceptible to EUS. The present study shows that the prevalence of EUS was $18.72 \%$ which was closely related to the result of Faruk et al. (2004) who found 18.9\% in northern part of Bangladesh. Similar results also reported by Hossain et al. (1992) and Ahmed and Rab (1995). During 1988 - 1989 the estimated economic losses by EUS disease in Bangladesh was US\$ 4.8 million (Barua 1990). The fish farmers of the investigated area informed that after heavy rainfall and at the winter season 
when temperature was low, the symptoms of EUS usually seen and caused heavy mortality of fish.

Tail and fin rot was the second most familiar disease problem reported by the farmers. The common symptoms of the disease are rotting at tail of the affected fish and very often the fins. The causative organism may be bacteria usually called Cytophaga but previously it was called Flexibacter and also Myxobacteria. However, the disease may developed by many factors such as badly handled, undue stress, sudden increase the temperature and hardness and low pH of the water. Faruk et al. (2004) reported that tail and fin rot disease was major disease problem in freshwater fishes in northern part of Bangladesh which is closely related to the present investigation.

The bacterial gill rot disease was also reported by the farmers. The causative agent of this disease is Flavobacterium sp. (Wakabayashi 1989) which is a gram negative bacteria. The affected gills appear swollen and mottled sometimes gill lamellae is deformed. Faruk et al. (2004) reported the same disease symptoms in Dinajpur and Mymensingh district of Bangladesh.

Farmers also reported the parasitic disease and the present study found that carp fishes were widely affected by Argulus. Usually parasite acts either as a pathogen or as vector for diseases. Highest mortality of carp fingerlings was observed which infected by protozoans and monogenean parasites in nurseries (Hossain et al.1994). Fish fry at the young stage become more susceptible to pathogen because of their undeveloped immune system (Anderson 1974) which supports the present findings.

Broken antennae and rostrum disease of Macrobrachium rosenbergii was also reported by the farmers in polyculture farms at Bagerhat and Khulna district. The exact causing agent of this disease is not known. Ravi Kumar et al. (2004) documented a new disease, viz. appendage deformity syndrome (ADS), in $M$. rosenbergii that results in high mortality. Their findings suggest that carotenoid deficiency may cause the disease. Infected prawns show unusual gross signs like appendage deformity, broken or bent rostrums, cut antennae, wrinkled carapace, white color ovaries and higher rates of mortality. The gross signs of this disease are more prevalent in females than males and disease often seen after 4 to 6 months of culture.

In the present investigation, farmers reported that they have observed red spot on their fishes. The symptom of this disease is the presence of red spot at the base of the dorsal fins and over the skin. Faruk et al. (2004) reported that motile aeromonad (Aeromonas hydrophila) was major causative agent of this disease. However, poor water quality, high stocking density and undue stress could boost up this disease. 


\section{CONCLUSION}

The present study revealed that the exposure of fish disease by the farmers was very poor because lack of awareness about fish disease and also due to reporting places which was far away from the farmer's culture area. As a result, there were huge lack of taking preventive and control measures by the farmers. This study indicated that there are considerable fish disease problems in the investigated areas and these problems should not be undermined since this area are potential for fish cultivation in Bangladesh.

\section{LITERATURE CITED}

AHMED, M. and RAB, M.A. 1995. Factors affecting outbreaks of epizootic ulcerative syndrome in farmed fish in Bangladesh. J. Fish Diseases 18: 263-271.

AHMED, N., WAHAB, M.A. and THILSTED, S.H. 2007. Integrated aquaculture-agriculture systems in Bangladesh: potential for sustainable livelihoods and nutritional security of the rural poor. Aquaculture Asia 12(1): 14-22.

ANDERSON, D.P. 1974. Fish Immunology. In: Diseases of Fishes (Ed.), Stanisias, F., Sneiszko, F., Axelrod. H.R.F.H. Publication Inc. New Jersey, USA.

BARUA, G. 1990. Bangladesh Report. In: Phillips, M.J. and Keddie, H.G. (Eds.). Regional Research Programme on Relationships between Epizootic Ulcerative Syndrome in Fish and the Environment. A Report of the Second Technical Workshop, 13 - 26 August, 1990. Network of Aquaculture Centers in Asia and the Pacific.

BER. 2015. Bangladesh Economic Review. Finance Division, Ministry of Finance, Government of the Peoples Republic of Bangladesh, Dhaka. pp. 79-92.

DFS. 2015. Disease Fact Sheet. Epizootic Ulcerative Syndrome (EUS) (http://www.wwt.org.uk/ uploads/documents/1341561575_RWDM4DiseaseFactsheetsEpizooticulcerativesyndromeEUS. pdf) Retrieved on 13.07.2015.

DoF. 2015. Department of Fisheries. Annual Report. Fisheries Resources Survey Systems, Dhaka, Bangladesh.

DoF. 2010. Department of Fisheries. Fishery Statistical yearbook of Bangladesh 2009-2010. Fisheries Resources Survey Systems, Dhaka, Bangladesh. 113 pp.

EDWARDS, P. and DEMAINE, H. 1997. Rural Aquaculture Overview and Framework for Country Reviews. RAP publication 1997/36. RAP, Bangkok, Thailand. 61 pp.

FAO, 2010. State of World Aquacultutre- Fisheries Department. FAO Fisheries Technical Paper 500, 21-26.

FARUK, M.A.R., ALAM, M.J., SARKER, M.M.R. and KABIR, M.B. 2004. Status of fish disease and health management practices in rural freshwater aquaculture of Bangladesh. Pak. J. Biol. Sci. 7(12): 2092-2098.

HOSSAIN, M.S., ALAM, M. and MAZID, M.A. 1992. Survey of fish disease epizootic ulcerative syndrome in Chandpur District. Bangladesh J. Training and Dev. 5: 55-61.

HOSSAIN, M.A., BANU, A.N.H., KHAN, M.H. and SULTANA, N. 1994. Bacterial microflora isolated from carp and catfish fry and their sensitivity to some antibiotics. Bangladesh J. Microbiol. 11(2): 95-101. 
HOSSAIN, M.K., ISLAM, K.T., HOSSAIN, M.D. and RAHMAN, M.H. 2011. Environmental impact assessment of fish diseases on fish production. J. Sci. Foundation 9(1\&2): 125-131.

ISLAM, M. N. 2001. An overview of aquaculture development in Bangladesh. Aquaculture Asia 6: 4-9.

LILLEY, J.H., CALLINAN, R.B., CHINABUT, S., KANCHANAKHAN, S., MacRAE, I.H. and PHILLIPS, M. J. 1998. Epizootic Ulcerative Syndrome (EUS) Technical Handbook. The Aquatic Animal Health Research Institute, Bangkok. 88 pp.

RAVIKUMAR A., VENKATESWARA, R.G. and SAMBASIVA, K.R.S. 2004. Appendage deformity syndrome a nutritional disease of Macrobrachium rosenbergii. Dis. Aquatic Org. 59: 75-78.

WAKABAYASHI, H., HUH, G.J. and KIMURA, N. 1989. Flavobacterium branchiophila sp. nov. a Causative Agent of Bacterial Gill Disease of Freshwater Fishes. Int. J. Sys. Bact. 39(3): 213-216.

(Manuscript received on 09 September, 2015; revised on 12 June, 2016) 